IZA DP No. 4195

Intrapreneurship or Entrepreneurship?

Simon C. Parker

May 2009 


\title{
Intrapreneurship or Entrepreneurship?
}

\author{
Simon C. Parker \\ University of Western Ontario \\ and IZA
}
Discussion Paper No. 4195
May 2009

\author{
IZA \\ P.O. Box 7240 \\ 53072 Bonn \\ Germany \\ Phone: +49-228-3894-0 \\ Fax: +49-228-3894-180 \\ E-mail: iza@iza.org
}

\begin{abstract}
Any opinions expressed here are those of the author(s) and not those of IZA. Research published in this series may include views on policy, but the institute itself takes no institutional policy positions.

The Institute for the Study of Labor (IZA) in Bonn is a local and virtual international research center and a place of communication between science, politics and business. IZA is an independent nonprofit organization supported by Deutsche Post Foundation. The center is associated with the University of Bonn and offers a stimulating research environment through its international network, workshops and conferences, data service, project support, research visits and doctoral program. IZA engages in (i) original and internationally competitive research in all fields of labor economics, (ii) development of policy concepts, and (iii) dissemination of research results and concepts to the interested public.
\end{abstract}

IZA Discussion Papers often represent preliminary work and are circulated to encourage discussion. Citation of such a paper should account for its provisional character. A revised version may be available directly from the author. 
IZA Discussion Paper No. 4195

May 2009

\section{ABSTRACT}

\section{Intrapreneurship or Entrepreneurship?}

I explore the factors that determine whether new business opportunities are exploited by starting a new venture for an employer ('nascent intrapreneurship') or independently ('nascent entrepreneurship'). Analysis of a nationally representative sample of American adults gathered in 2005-06 uncovers systematic differences between the drivers of nascent entrepreneurship and nascent intrapreneurship. Nascent entrepreneurs tend to leverage their general human capital and social ties to organize ventures which sell directly to customers, whereas intrapreneurs disproportionately commercialize unique new opportunities which sell to other businesses. Implications of the findings are discussed.

JEL Classification: L26, M13

Keywords: nascent entrepreneurship, intrapreneurship, sample selection

Corresponding author:

Simon C. Parker

Richard Ivey School of Business

University of Western Ontario

1151 Richmond St

London, Ontario N6A 3K7

Canada

E-mail: sparker@ivey.uwo.ca 


\section{Introduction}

Intrapreneurship — also known as corporate entrepreneurship and corporate venturing (Burgelman 1983; Burgelman 1984; MacMillan et. al. 1986) — is the practice of developing a new venture within an existing organization, to exploit a new opportunity and create economic value (Pinchot 1985). Entrepreneurship by contrast is the act of developing a new venture outside an existing organization. There is evidence that intrapreneurship helps managers to renew and revitalize their businesses, to innovate, and to enhance their overall business performance (Kuratko et. al. 1990; Antoncic and Hisrich 1990). It is therefore of interest to investigate which factors are associated with efforts to start new ventures for an employer by 'nascent intrapreneurs', and which are associated instead with independent start-ups by 'nascent entrepreneurs' — where the word 'nascent' refers to emergent (i.e., not yet completed) start-up activity. The present article explores this question.

Previous research has identified several reasons why new opportunities might be exploited via entrepreneurship rather than intrapreneurship. These include agency costs which affect contracting between employees and employers; transferable human capital and limited asset complementarity within existing firms; and organizational limitations of incumbents such as bureaucracy and rigid routines (Henderson 1993; Anton and Yao 1995; Klepper 2001; Helfat and Lieberman 2002). However, to date there is only limited empirical evidence about the factors promoting entrepreneurship rather than intrapreneurship. Instead, the evidence base is mainly concerned with: linking the market entry strategies and performance outcomes of new spinoffs to the performance of parent firms (Christensen 1993; Helfat and Lieberman 2002; Gompers et. al. 2005; Klepper and Thompson 2006); organizational factors which influence intrapreneurship (Pinchot 1985; Hornsby et. al. 2002); the effects of intrapreneurship on corporate performance (Lumpkin and Dess 1996; Zahra and Gravis 2000); and characteristics of intrapreneurs (Fayolle 2004; Howell and Higgins 1990a).

This article develops theoretical arguments and testable hypotheses about the factors promoting nascent intrapreneurship relative to nascent entrepreneurship. These arguments principally draw on contributions from human capital theory and incentive (agency) theory. The article utilizes data from a relatively large and representative publicly-available survey of American adults, the PSED 
II (www.psed.isr.umich.edu). This dataset makes a clean distinction between NE and NI startups, and contains a rich array of explanatory variables about individuals and their products; the processes they follow; and the organizational environments they operate in, including information about their current or former employers (Aldrich 1999; Menzel et. al. 2007). The PSED II also contains information about people who choose neither intrapreneurship nor entrepreneurship. This makes it possible to deal with the possibility that nascent intrapreneurs and entrepreneurs self-select non-randomly into these activities.

Dealing with sample selection turns out to be crucial for deriving accurate empirical results. The findings reveal a central role for general human capital, which promotes start-up organizing efforts in general, and nascent entrepreneurship (rather than nascent intrapreneurship) in particular. While previous research has already identified general human capital as an important determinant of start-up efforts in general (e.g. Davidsson and Honig 2003), its influence on NE relative to NI is less well known. Furthermore, it is found that independent starts are more likely to exploit ideas which involve talking to customers rather than researching established competitors, and which leverage social ties as well as general human capital. In contrast, incumbent firms tend to pursue intrapreneurship by developing unique business-to-business products which seem to be harder for employees to transfer into independent start-up efforts.

We believe that these results are not only interesting in their own right but also could prove informative for theory and practice. For example, because the (observable) characteristics of individuals, their current or more recent workplaces, and their proposed new products all turn out to affect the decision to do NI or NE, future theories might need to be enriched to draw on a broader range of considerations than has been the case hitherto. In particular, our findings suggest the need for future theory to extend the scope of inquiry from that of the individual employee to take greater account of the objectives, capabilities and limitations of the organizations they work for. Strategic interactions between agents in this context are likely to be both interesting and wide-ranging. Future theory development might also fruitfully delve deeper into the self-selection mechanisms (based on unobservable characteristics) which our empirical investigation uncovers. 
The next section develops theoretical arguments and testable hypotheses about the factors promoting NI relative to NE. The section that follows it explains the dataset, including key explanatory variables and control variables. The fifth section outlines the empirical methods used to test the hypotheses. The sixth section presents the results. The final section concludes.

\section{Theory}

A large body of theoretical research emphasizes the importance of human capital for understanding the determinants of start-up organizing efforts. It is convenient at the outset to follow Becker (1964) by distinguishing between 'general' and 'specific' human capital. General human capital comprises skills, knowledge, experience and capabilities (such as those embodied in formal education) which are useful in a multitude of productive uses, including both existing organizations and new venture creation. Specific human capital in contrast refers to skills, experience, knowledge and capabilities, such as those imparted by firm-specific training programs, which are primarily useful to the organization which provides them.

The distinction between general and specific human capital helps to elucidate implications of an agency problem studied by Anton and Yao (1995), in which an employee identifies a new venture opportunity which can be exploited either inside or outside the firm. The employee can keep the opportunity secret, and quit the firm in order to exploit it in a new independent firm (NE); or she can disclose it to the firm in the hope of sharing in the profits resulting from joint development (NI). The greater an employee's general human capital, the greater is their capability to exploit the opportunity outside the firm in independent NE (Zucker et. al. 1998). General human capital is associated with analytical ability, knowledge about business opportunities and conditions, and computational and communication skills which are readily transferable between organizations. In contrast, an employee's general human capital may be less relevant for developing the opportunity via NI if the firm can substitute other workers' general human capital to develop the idea once it has been revealed to them. Hence one might expect general human capital to be more associated with NE than with NI activity. 
The value of new venture opportunities discovered within firms is frequently enhanced by complementarities with other assets specific to the firm (Teece 1986; Subramanian 2005). For example, an employee's specific human capital can affect the development trajectory of a new idea, culminating in an innovation which is complementary to the internal organization of the firm and hence more valuable if exploited within it. In such cases, intrapreneurship would appear to be a logical option. But although specific human capital might be difficult to transfer outside incumbent firms owing to formal barriers (e.g. non-compete agreements) and informal barriers (e.g. embedded organizational skills), it is less obvious which aspects of specific human capital are truly specific to the firms they are acquired in. Indeed, several theories of independent spinoffs argue that 'specific' human capital is actually more transferable outside the firm than it first appears (Helfat and Lieberman 2002; Møen 2005).

Consider, for example, knowledge about a firm's internal organizational routines, which is an important kind of specific human capital (Nelson and Winter 1982; Klepper 2001). Although this knowledge might be redundant in other incumbent firms, employees leaving a firm to start a new independent venture might be able to replicate and transfer these routines to the new venture to better exploit their opportunities (Klepper 2001; Freeman and Engel 2007). In which case, what appears to be specific human capital might actually promote NE as well as NI activity, having more ambiguous effects on choices of commercialization mode than general human capital does.

These ideas are summarized in the following hypothesis:

Hypothesis 1. General human capital makes NE more attractive relative to NI, and has stronger effects on the mode of commercialization than specific human capital.

Other firm-specific assets include established marketing, sales, design and logistics departments, which are set up to service a firm's existing operations but which can also work with a new internal product line. The existence of these assets; a reputation for providing a stable and trusted source of supply; and greater legitimacy relative to new independent start-ups, give incumbent firms an advantage over new independent ventures in commercializing new opportunities, whether of 
the business-to-business (B2B) or business-to customer (B2C) sort. However, it seems likely that incumbent firms have a comparative advantage over new ventures in $\mathrm{B} 2 \mathrm{~B}$ rather than $\mathrm{B} 2 \mathrm{C}$ sales (Claycomb et. al. 2005). The reasoning is as follows. Few independent start-ups have access to the resources needed to supply other businesses (especially legitimacy and reputation), and instead are likely to have a comparative advantage in forging $\mathrm{B} 2 \mathrm{C}$ relationships whose effectiveness depends on flexible adjustment to fast-changing consumer demand. In these circumstances, incumbents' routines can be a positive disadvantage, since redeploying resources from their current uses can cause inefficiencies as managers of incumbent firms strive to retain those resources to support the projects for which they are responsible. This can allow independent entrepreneurship to exploit profitable (though possibly short-lived) niches (Audretsch and Thurik 2001; Freeman and Engel 2007).

Hypothesis 2. Business-to-business opportunities are associated more with NI than NE commercialization: business-to-customer opportunities are associated more with NE than NI.

Anton and Yao (1995) argue that greater personal wealth enables an employee to contract more effectively with their employer. Anton and Yao (1995) consider a contract under which, in return for posting a bond to the employer, an employee who chooses joint commercialization is guaranteed a stake of the profits. This contract removes the risk of expropriation by the employer and makes the employee willing to reveal their discovery — so promoting NI commercialization. In contrast, employees lacking wealth cannot post a bond. Being exposed to the threat of expropriation, they are likelier to take their opportunity outside the firm, via the NE route. Hence wealth may be necessary for NI exploitation.

A different argument proposes a positive relationship between available income and the probability of the NI mode. Managers wishing to discourage employees from quitting to found potentially competing start-ups might seek to 'buy them off' with higher salaries, which helps retain both the employee and the innovation within the firm (Møen 2005; Subramanian 2005; Hvide and Kristiansen 2007; Hvide 2009). More generally, it has been argued that even when employers lack 
complementary assets and property rights, they can still design compensation contracts which successfully retain employees with valuable new ideas within the firm (Pakes and Nitzan 1983; Anton and Yao 1994; Møen 2005). For these reasons, I propose the next hypothesis:

\section{Hypothesis 3. Greater personal wealth and income make NI more attractive relative to NE.}

The types of products commercialized by new start-ups are also likely to differ between NE and NI modes. Large firms can spread the risks of innovation, giving them greater incentives to engage in the risky activity of radical innovation. They also perform more R \& D (Cohen and Klepper 1992), which is often needed to pioneer new innovations. Both of these arguments suggest that NI is associated with unique products. Incumbents also have greater incentives to innovate in order to retain monopoly profits than new independent entrants, since the latter can at best obtain duopoly profits by competing with incumbents (Gilbert and Newbery, 1982). Furthermore, an incumbent is more likely to support a corporate venture innovating a unique new product which does not compete with (i.e. cannibalize the profits from) the incumbent's existing product line. And a new product presumably has to be sufficiently different from a firm's existing product line in order for it to be commercialized as a new business unit (NI) rather than via simply internal expansion.

Another set of incentives is pertinent for managers who try to motivate their employees to work on a main task. Managers can often do best by committing to a policy of passing up mundane innovations discovered by employees to keep them focused on their main task; it only pays managers to break this policy rule and back NI when unique, valuable projects emerge (Hellmann 2007).

On the other hand, unique new products can create their own problems for corporations. They can disrupt valuable organizational routines which work smoothly and effectively for the firm's existing product lines. And they can threaten to render obsolete the expertise underlying the careers of managers responsible for deciding the innovation strategy of the firm. As a result, managers may prefer to back relatively predictable incremental innovations rather than ambitious radical ones (Bhide 2000; Freeman and Engel 2007). Furthermore, uncertainty associated with unique new products can promote divergent opinions between employees and employers about the value 
of a discovery. That makes it less likely that both parties will agree on initiating a corporate venture (Audretsch 2001; Klepper and Sleeper 2005). Hence managers wishing to encourage NI may need to obtain objective information to convince sceptics within their organizations about a new corporate venturing opportunity, especially if it is based around a unique new product. In particular, managers may need to acquire information about competitors who might also be working on similar developments. With this information in place, incumbent firms should be more willing to adjust routines and resolve internal conflicts to facilitate intrapreneurship. Hence we might expect research about competitors to promote NI commercialization directly, as well as to moderate positively the relationship between the uniqueness of a venture's product and the likelihood of NI commercialization. These arguments are summarized in the next hypothesis:

Hypothesis 4. Products or services with unique attributes are more likely to be developed via NI than NE. NI exploitation of these opportunities entails research about competitors, which both promotes NI commercialization directly and moderates positively the relationship between the uniqueness of a venture's product and the likelihood of NI commercialization.

Entrepreneurship researchers have established that people who are engaged in start-up activities, whether NE or NI, are not representative of the population but are instead a self-selected group, amounting to no more than $6 \%$ of the American adult population (Gartner et. al. 2004; Reynolds et. al. 2004). If these self-selected individuals have unobserved attributes which predispose them to a particular mode of entry, then it is important to take this into account when analyzing empirically NI-NE outcomes. For example, consider two hypothetical individuals, A and B, where A has unobserved attributes which predispose them to entrepreneurial-type work over corporate wage-and-salary work, unlike B who prefers the corporate environment. It seems plausible given these preferences that B is more likely (all else equal) to engage in NI if they try a start-up at all. In contrast, independence-seeking A is more likely (all else equal) to engage in NE if they try a start-up at all. 
Hypothesis 5. Individuals engaged in new firm founding efforts are a self-selected group. Unobserved attributes that predispose individuals to work on a start-up in general rather than work in a corporate environment also predispose them to prefer NE to NI.

To date, the empirical literature on nascent entrepreneurship (Gartner et. al. 2004; Davidsson 2006) has placed greater emphasis on observable characteristics that may be associated with a propensity to engage in some form of start-up activity, whether NE or NI. The underlying rationale rests in part on human capital theory and opportunity cost logic (Davidsson 2006). For example, if general human capital is more (respectively, less) valuable in new business venturing (whether $\mathrm{NE}$ or NI) than in traditional corporate employment, then highly educated and experienced people are more (respectively, less) likely to engage in new venturing activity. The US evidence is broadly consistent with this prediction (Davidsson 2006; Kim et. al. 2006).

Another important aspect of general human capital is age, since human capital theory suggests that individuals who are neither too young nor too old are most likely to engage in business startups, all else equal (Lévesque and Minniti 2006). People of an intermediate age have not only acquired enough human, social and financial capital to have reasonable prospects of launching a successful new venture, but also anticipate a sufficiently prolonged stream of returns from their investment to make it worthwhile. Previous evidence on nascent entrepreneurs has borne out this conjecture as well (Delmar and Davidsson 2000; Davidsson 2006). These arguments are summarized in the final hypothesis:

Hypothesis 6. General human capital makes start-up organizing activities, whether NE or NI, more attractive relative to non-start-up organizing activities.

\section{Data}

The discussion in the previous section highlights the need for a dataset which contains information relating to two questions. These are: factors affecting selection into any kind of start-up organizing activity; and factors affecting NI relative to NE for the self-selected group of individuals choosing start-up organizing activity. The newly-released publicly-available PSED II dataset contains 
two surveys corresponding exactly to these two questions. The first is a nationally representative 'Screener' telephone survey, conducted between October 2005 and January 2006, of 31,845 American adults aged 18 and over. A total of 1,214 adults engaged in starting up a new venture were identified from the Screener. The second survey derives from a 'Follow-up' telephone interview (called 'Wave A' in the PSED II documentation) conducted immediately after the Screener and lasting one hour, of the 1,214 nascent intrapreneurs and entrepreneurs. Further details about the PSED II research design and methodology, questionnaires, variable definitions and data samples can be freely downloaded from the website www.psed.isr.umich.edu.

The most widely used definition of a nascent entrepreneur in empirical research is somebody who satisfies all four of the following criteria: 1) they consider themselves to be involved in the firm creation process, 2) they have engaged in some start-up activity in the past 12 months, 3) they expect to own all or part of the new firm, and 4) their initiative has not progressed to the point where it may be considered an operating business. For consistency, nascent intrapreneurs are classified in a similar way but report that they are engaged in start-up activities for their employer, as part of their normal work. This definition is consistent with the definition of intrapreneurship given at the start of this article, namely of developing a new venture within an existing organization (Pinchot 1985). These definitions yield two distinct and non-overlapping groups of NIs and NEs.

For completeness, I also explored two alternative definitions of NI and NE status in the PSED II, based on 'type of business' and 'business ownership'. However, neither of these alternatives turned out to be satisfactory. The 'type of business' variable contains a category 'new businesses sponsored by an existing business'. Unfortunately, it is unclear what 'sponsorship' means in this context, as the majority of these 'sponsored' businesses do not cede any ownership stake to any other stakeholder, including a sponsoring business. Nor does the PSED II contain enough information to operationalize an alternative definition based on employer ownership shares alone. Perhaps even more fundamentally, however, neither 'sponsorship' nor 'ownership' is a necessary or sufficient condition for intrapreneurship. Numerous intrapreneurial ventures are operated on an 'arms length' 
and self-sustaining basis, obviating the need for overt sponsorship; while some intrapreneurial ventures can involve family business owners 'gifting' new business opportunities to their friends or relatives without taking an ownership stake.

Based on the chosen definitions of NI and NE described above, of the 1,214 people engaged in start-up activities at the time of interview, 269 cases were classified as nascent intrapreneurs, NI, and the remaining 945 were classified as nascent entrepreneurs, NE. This yields two binary dependent variables: whether an individual engages in start-up activity or not, and if so whether they do as a NI or a NE.

The sample was restricted to exclude retired people. By definition, retirees cannot be genuine nascent intrapreneurs because they do not have a current employer. This reduced the sample size from 31,845 to 22,741 observations. The sample was not restricted in any further respect, and contains members of both genders operating across a range of industries and various ethnicities. Every calculation performed in this article reweights the sample data using the screener interview weights provided with the dataset. These weights correct for differences in sample inclusion probabilities and differential non-response rates. Data on sex, age, household income and race taken from the March 2005 Current Population Survey conducted by the US Census Bureau were used to construct the weights. The use of these weights ensures that the data are representative of the US population, enabling the researcher to make robust and generalizable inferences.

\subsection{Whether to try a start-up: Screener variables}

The Screener dataset contains several general human capital variables corresponding to those outlined in Hypotheses 1 and 6. They include the highest educational qualifications achieved, namely High School, Some College, College Degree, and Postgraduate. These are coded as dummy variables; the base category is 'less than high school'. Several age categories are also coded as dummy variables, notably Age 18-24, Age 25-34, Age 35-44 and Age 45-54. The base category is '55 and over'. In terms of general non-formal skills, the Screener contains information about whether respondents use the Internet at home. The variable Internet is coded as one if they do, and zero otherwise. The 
use of this variable is also consistent with previous research. For example, using matched CPS and Computer and Internet Usage data from 1997-2001, Fairlie (2006) showed that computer usage is associated with a higher probability that American adults become business owners, not only in the IT sector but across a range of industries.

Previous research has also identified several other determinants of start-up activity, which can be treated as control variables in the present context. These include family circumstances, sociodemographic factors and regional characteristics (Davidsson 2006). The Screener records whether an individual is a Household Head (not necessarily male), Married, Works Full-time, and is an Owner Occupier. Household heads are most likely to engage in some form of economic activity, so this variable controls for the labor force participation decision. Full-time, married owner-occupiers are especially likely to have domestic responsibilities which deter them from engaging in risky start-up activities: this theme is elaborated on below in the empirical discussion of the model identification strategy. The following control variables are also included: a dummy for Female gender; a dummy for whether the individual is responsible for Young Children (aged under six years); and a continuous variable measuring Household Size. These factors have all been emphasized in previous work (Edwards and Field-Hendrey 2002). Participation in start-ups is also known to vary by ethnicity (Kim et. al. 2006), so dummies for African-American and Latino heritage are added as well (there were insufficient cases to analyze separately Asian-Americans). Also drawing on previous research in nascent entrepreneurship, dummy variables for broad geographical regions and whether the location of the start-up is Urban are included to control for regional variations in opportunities (Reynolds et. al. 2004; Wagner and Sternberg 2004).

\subsection{Whether to do a start-up by NI or NE: Follow-up variables}

The Follow-up dataset contains information about the current workplace (for those trying to start up while in paid-employment) or the most recent workplace (for those trying to start up after quitting a previous spell of paid-employment). Specific human capital (Hypothesis 1) is notoriously difficult to measure directly; but it seems plausible that the longer a respondent has worked for 
their most recent employer, the greater their exposure to that organization and the greater their chances of acquiring specific human capital. Furthermore, managers, especially those who supervise numerous employees seem especially likely to have broad firm-specific knowledge, including familiarity with organizational routines, which as suggested earlier can facilitate corporate venturing (and possibly also independent venturing if routines can be replicated outside the firm). I therefore measure specific human capital using continuous variables for Job Tenure (measured in log years) and the No. of Supervisees in the current or previous job; and also by a dummy variable for being a Manager in the current or previous job.

Turning to Hypothesis 2, respondents in the Follow-up survey report the percentage of their sales projected to come from Business-to-Business sales (B2B Sales). One concern with using this variable is that it might be tautologically related to nascent intrapreneurship if parent firms expect there to be major B2B collaborations in future between themselves and the intrapreneurial venture. If so, NI ventures would have incentives to locate close to parent firms. To check this possibility, I examined data on the percentage of new ventures' customers expected to be located within twenty miles of the new venture in the first two to three years after start-up. If the variable B2B Sales merely reflects collaborations with the parent firm, responses for NIs to this question should be significantly higher than for NEs. In fact, the figure was only $59.1 \%$ for NIs, compared with $61.1 \%$ for NEs. This difference, which is statistically insignificant, suggests that B2B Sales is capturing more than tautological linkages between nascent intrapreneurship and future collaboration opportunities.

Cardinal data on the natural logarithm of household income Log Income and net household wealth Wealth (measured in millions of US dollars, and taking negative as well as positive values) are used to test Hypothesis 3. To test Hypothesis 4, respondents who declared that some or all of their potential customers would regard the new product as 'new and unfamiliar' had values of the variable Unique Product coded as unity; those which did not had zero values. Another dummy variable registers whether market research on competitors was performed (Competitor Information). The interaction between these variables is denoted by Unique $\times$ Competitor. 
The Follow-up dataset also contains an extensive range of control variables relating to: industry sector; the nature of the product, its intended market and market research; and the workplace of the current or most recent employer. By controlling for these other factors, cleaner tests of the hypotheses of interest can be performed.

Industry Sector Much of the literature on corporate venturing focuses on high value-added sectors, such as Professional, Scientific and Technical (PST). Indeed, 19\% of the start-up efforts in the sample appear in the PST sector, compared with $8 \%$ in Finance, Insurance \& Business and $10 \%$ in Construction. The largest sectors for start-up activity are Customer Service (34\% of all start-up efforts) and Trade (23\%). Although the sectoral composition of NI and NE activity is very similar, dummy variables for these sectors are included in all of the empirical estimations below which use Follow-up data.

Product and Market The corporate venturing literature focuses largely on high-tech and newtech products (Menzel et. al. 2007). It is desirable to control for these product types to ensure that choices for NI relative to NE are not simply being driven by differences in the nature of the products being developed. Dummy variables classifying whether the product being developed in the start-up effort is High Tech or New Tech are used to control for product type, where new-tech products are those requiring technologies or procedures which were generally unavailable more than five years ago.

Other potentially relevant product characteristics include whether the new venture will compete on Quality (as opposed to price); whether it will embody Proprietory Technology (the base category is that it does) or is Protected by a Patent (the base category is that it is); and whether Equipment was Purchased already. The literature does not offer unambiguous theoretical predictions about whether greater intellectual property rights generally favor NI or NE. The outcome partly depends which party who owns the IPR and the value of the innovation relative to a firm's existing product lines (Hellmann 2007; Hvide and Kristiansen 2007).

Previous research has identified the clear framing of business opportunities and business planning to exploit them as potentially important aspects of start-up planning and execution (Delmar and 
Shane 2004). To control for the possibility that different modes of commercialization are associated with different types of business planning, I include dummy variables for whether the Opportunity was Defined at the outset; whether a Current Business Plan had been begun; whether a Future Business Plan was projected; and whether the entrepreneur(s) had already Talked to Customers. There are also continuous variables measuring the percentages of projected sales intended for Government Sales, and the percentage of the product's market targeted at a Regional Market or the National/International Market. The rationale for including these control variables is once again to ensure that choices for NI relative to NE are not simply being driven by differences in the nature of the products being developed.

Current or Most Recent Workplace Characteristics of the current or most recent workplace might determine opportunities to do corporate venturing. These opportunities could be more abundant in Private Growth firms than in Private Static firms (both measured as dummy variables). Size effects are controlled for by Employer Size, measured as the logarithm of the number of people on the payroll at the most recent workplace. To capture possible gender differences transmitted within current or previous workplaces, two other dummy variables record whether the workplace was Male Dominated or Female Dominated, as opposed to neither.

Finally, prior research suggests that NI projects are more likely to flourish if they receive support from 'champions' inside the firm, such as senior managers (Howell and Higgins 1990a; Howell and Higgins 1990b). Such support can be harder to obtain in companies with large bureaucracies, especially where there is a long line of control 'distance' between the potential entrepreneur and the CEO. To control for this possibility, the variable Distance to CEO measures the logarithm of the number of employees intervening between the respondent and the CEO. The greater the distance, the more difficult it could be to gain support from senior managers. However, values of this variable (and also of Employer Size) are estimated by respondents and so may be prone to mis-measurement. Any systematic under- or over-reporting, by some scale factor $k$, will be partialed out into the intercept ( $\operatorname{since} \log (k x)=\log k+\log x$ ); but any remaining non-systematic (random) errors mean that results based on these variables should be interpreted with caution. 
Table 1 Descriptive statistics

\begin{tabular}{|c|c|c|c|c|c|c|c|c|c|}
\hline \multicolumn{5}{|c|}{ Screener } & \multicolumn{5}{|c|}{ Follow-up } \\
\hline \multirow[t]{2}{*}{ Variable } & \multicolumn{2}{|c|}{ Mean } & \multirow[t]{2}{*}{$\mathrm{N}$} & \multirow[t]{2}{*}{$p$} & \multirow[t]{2}{*}{ Variable } & \multicolumn{2}{|c|}{ Mean } & \multirow[t]{2}{*}{$\mathrm{N}$} & \multirow[t]{2}{*}{$p$} \\
\hline & $S=1$ & $S=0$ & & & & NI & $\mathrm{NE}$ & & \\
\hline & & & & & $\mathrm{NI} / \mathrm{NE}$ & 0.23 & 0.77 & 1,214 & \\
\hline High School & 0.21 & 0.28 & 22,472 & 0.00 & Job Tenure & 1.28 & 1.38 & 1,211 & 0.11 \\
\hline Some College & 0.35 & 0.27 & 22,472 & 0.00 & Manager & 0.26 & 0.23 & 1,206 & 0.23 \\
\hline College Degree & 0.24 & 0.24 & 22,472 & 0.52 & No. Supervisees & 14.14 & 21.53 & 1,179 & 0.21 \\
\hline Postgraduate & 0.12 & 0.13 & 22,472 & 0.27 & $\%$ B2B Sales & 26.04 & 22.33 & 1,157 & 0.09 \\
\hline Age $18-24$ & 0.13 & 0.16 & 22,418 & 0.00 & Log Income & 10.82 & 10.85 & 19.813 & 0.33 \\
\hline Age $25-34$ & 0.27 & 0.23 & 22,418 & 0.00 & Wealth & 0.26 & 0.67 & 1,005 & 0.33 \\
\hline Age $35-44$ & 0.28 & 0.25 & 22,418 & 0.01 & Unique Product & 0.26 & 0.17 & 1,214 & 0.00 \\
\hline Age $45-54$ & 0.22 & 0.22 & 22,418 & 0.97 & Competitor Info & 0.53 & 0.52 & 1,214 & 0.86 \\
\hline Internet & 0.78 & 0.69 & 22,741 & 0.00 & Unique $\times$ Competitor & 0.11 & 0.07 & 1,214 & 0.02 \\
\hline H Head & 0.88 & 0.85 & 22,637 & 0.00 & High-Tech & 0.26 & 0.23 & 1,214 & 0.23 \\
\hline Married & 0.55 & 0.58 & 22,473 & 0.06 & New-Tech & 0.23 & 0.22 & 1,214 & 0.76 \\
\hline Full-Time & 0.65 & 0.64 & 22,741 & 0.75 & Quality & 0.36 & 0.40 & 1,214 & 0.24 \\
\hline Owner-Occ & 0.64 & 0.71 & 21,745 & 0.00 & No Proprietory Tech. & 0.78 & 0.78 & 1,214 & 0.80 \\
\hline Female & 0.40 & 0.52 & 22,741 & 0.00 & No Patent & 0.68 & 0.72 & 1,214 & 0.20 \\
\hline Young Kids & 0.28 & 0.25 & 19,120 & 0.06 & Equipment Purchased & 0.37 & 0.44 & 1,214 & 0.03 \\
\hline H Size & 3.21 & 3.09 & 22,470 & 0.01 & Opportunity Defined & 0.41 & 0.45 & 1,214 & 0.29 \\
\hline African-Am & 0.19 & 0.13 & 22,570 & 0.00 & Current Business Plan & 0.51 & 0.49 & 1,214 & 0.65 \\
\hline Latino & 0.12 & 0.13 & 22,466 & 0.55 & Future Business Plan & 0.32 & 0.29 & 1,214 & 0.33 \\
\hline Urban & 0.35 & 0.31 & 22,741 & 0.03 & Talked to Customers & 0.59 & 0.70 & 1,214 & 0.00 \\
\hline & & & & & $\%$ Regional & 21.21 & 20.97 & 1,176 & 0.88 \\
\hline & & & & & $\%$ Nat/International & 20.36 & 18.87 & 1,171 & 0.46 \\
\hline & & & & & Private Growth & 0.34 & 0.35 & 1,191 & 0.89 \\
\hline & & & & & Private Static & 0.28 & 0.25 & 1,191 & 0.45 \\
\hline & & & & & Male Dominated & 0.35 & 0.27 & 1,202 & 0.02 \\
\hline & & & & & Female Dominated & 0.14 & 0.17 & 1,202 & 0.22 \\
\hline & & & & & Log Employer Size & 5.05 & 5.34 & 1,133 & 0.17 \\
\hline & & & & & Log Distance CEO & 1.37 & 1.29 & 1,185 & 0.29 \\
\hline
\end{tabular}

Notes: Data source: PSED II, non-retired sample. All statistics are weighted to be nationally representative.

$S$ takes the value one for anyone engaged in starting up a venture, whether as a nascent intrapreneur (NI)

or a nascent entrepreneur (NE); it is zero otherwise. $p=$ p-values, computed from $\chi^{2}(1)$ statistics for pairs of binary variables, and from ANOVA F-statistics for continuous variables.

Table 1 summarizes descriptive statistics for the dependent and explanatory variables. Fully $5 \%$ of survey respondents are engaged in some start-up activity, similar to previous estimates for the US economy (Reynolds et. al. 2004). The first part of the table compares those who do and do not engage in start-ups in the Screener dataset; the second part compares Follow-up covariates in terms 
of NI-NE outcomes. Some univariate statistical comparisons are given. Correlation matrices are suppressed for brevity but are freely available from the author on request; no serious collinearity problems were detected.

According to Table 1, people engaged in some kind of start-up activities are significantly more likely to be middle-aged, a male household head, African-American, to live in an urban area, to have some college education, to use the Internet and to live in larger households with children. They are less likely to be owner-occupiers. Conditional on being involved in start-up activities, NIs are significantly more likely than NEs to develop unique products (especially if this is combined with collecting information about competitors), to be male, and to work in male-dominated workplaces. NEs are significantly more likely than NIs to have purchased equipment and to have talked to customers. It should be borne in mind however that these univariate comparisons can only be indicative: multivariate analysis is required to identify robust conditional relationships.

\section{Estimation Methodology}

My goal is to explain the determinants of engagement in start-up activity, and of nascent intrapreneurship versus nascent entrepreneurship conditional on such engagement. To this end define the binary variables $I$ and $S$. Let $I_{i}=1$ if $i$ is observed in nascent intrapreneurship, and $I_{i}=0$ if $i$ is observed in nascent entrepreneurship. And let $S_{i}=1$ if $i$ engages in either type of start-up activity and $S_{i}=0$ if $i$ engages in no type of start-up activity. Notice that observations $I_{i}$ are only observed for $S_{i}=1$. Hence the appropriate empirical model is a sample-selection model.

Based on the discussion in the previous section, define the following vectors of explanatory variables:

- $X_{i}$ : A vector of explanatory variables from the Screener affecting $S_{i}$ but not $I_{i}$

- $Y_{i}$ : A vector of explanatory variables from the Screener affecting $S_{i}$ and potentially $I_{i}$

- $Z_{i}$ : A vector of explanatory variables from the Follow-up affecting $I_{i}$ but not $S_{i}$

The fact that $X$ variables affect only $S$, while $Z$ variables affect only $I$, reflects the structure of the PSED II dataset. As explained at the start of the next section, this structure can be used to identify the sample-selection model, which is a two-equation bivariate probit (BVP): 


$$
\begin{gathered}
S_{i}=\alpha_{0}+\left(\begin{array}{ll}
X_{i} & Y_{i}
\end{array}\right)\left(\begin{array}{l}
\alpha_{1} \\
\alpha_{2}
\end{array}\right)+\epsilon_{1 i} \\
I_{i}=\beta_{0}+\left(\begin{array}{ll}
Y_{i} & Z_{i}
\end{array}\right)\left(\begin{array}{l}
\beta_{1} \\
\beta_{2}
\end{array}\right)+\epsilon_{2 i}
\end{gathered}
$$

where

$$
\operatorname{cov}\left(\epsilon_{1 i}, \epsilon_{2 i}\right)=\Sigma=\left(\begin{array}{cc}
1 & \rho \\
\rho & 1
\end{array}\right)
$$

Following standard practice (e.g., Greene 2003), the disturbances $\epsilon_{1}$ and $\epsilon_{2}$ are assumed to be jointly normally distributed, with zero means, unit variances, and correlation coefficient $\rho$. Non-zero values of $\rho$ capture any sample selectivity in the nascent intrapreneur/entrepreneur choice. A positive value for $\rho$ implies that unobserved characteristics which predispose individuals to engage in startup activities also predispose them to NI. A negative value implies that a start-up predisposition is associated with NE. Recall that Hypothesis 5 predicts $\rho$ to be negative.

Estimation of the parameters in (1), (2) and (3) is performed by the method of Full Information Maximum Likelihood (FIML). FIML is the most efficient estimator because it exploits all of the data structure. It estimates simultaneously the $\alpha \mathrm{s}, \beta \mathrm{s}$ and $\rho$ by maximizing the log likelihood function

$$
\begin{aligned}
\ln L= & \sum_{I_{i}=1, S_{i}=1} \ln \Phi_{2}\left(\alpha_{0}+\left(X_{i} Y_{i}\right)\left(\begin{array}{c}
\alpha_{1} \\
\alpha_{2}
\end{array}\right), \beta_{0}+\left(Y_{i} Z_{i}\right)\left(\begin{array}{c}
\beta_{1} \\
\beta_{2}
\end{array}\right), \rho\right)+\sum_{S_{i}=0} \ln \Phi\left(-\beta_{0}-\left(Y_{i} Z_{i}\right)\left(\begin{array}{c}
\beta_{1} \\
\beta_{2}
\end{array}\right)\right) \\
& +\sum_{I_{i}=0, S_{i}=1} \ln \Phi_{2}\left(-\alpha_{0}-\left(X_{i} Y_{i}\right)\left(\begin{array}{c}
\alpha_{1} \\
\alpha_{2}
\end{array}\right), \beta_{0}+\left(Y_{i} Z_{i}\right)\left(\begin{array}{c}
\beta_{1} \\
\beta_{2}
\end{array}\right),-\rho\right)
\end{aligned}
$$

(Greene 2003), where

$$
\begin{aligned}
\Phi(a) & =\frac{1}{\sqrt{2 \pi}} \int_{-\infty}^{a} e^{-u^{2} / 2} d u=\frac{1}{2}\left(1+\operatorname{erf} \frac{a}{\sqrt{2}}\right) \\
\Phi_{2}(a, b, \rho) & =\frac{1}{2 \pi|\Sigma|^{1 / 2}} \int_{-\infty}^{a} \int_{-\infty}^{b} \exp \left\{-\frac{1}{2}(u v) \Sigma^{-1}(u v)^{T}\right\} d u d v \\
& =\frac{1}{2 \pi \sqrt{1-\rho^{2}}} \int_{-\infty}^{a} \int_{-\infty}^{b} \exp \left\{-\frac{u^{2}-2 \rho u v+v^{2}}{2\left(1-\rho^{2}\right)}\right\} d u d v
\end{aligned}
$$

are the distribution functions of the standard normal and bivariate normal distributions, respectively. All estimations were performed using LIMDEP 8.0. No problems of collinearity were identified by the estimation procedure. 


\section{Results}

This section has the following structure. The first part deals with the identification of the model. The second estimates a simple version of the BVP model (1)-(3) using just the Screener data. This enables Hypotheses 1, 5 and 6 to be tested. I also demonstrate here the biases that can occur if the sample-selection issue is neglected. Third, Follow-up data are utilized to test the remaining hypotheses. Finally, several robustness checks are performed.

\subsection{Identification}

The model given by (1), (2) and (3) is identified by specifying some $X$ variables which affect $S$ but not $I$. This entails imposing one or more exclusion restrictions on the $I$ equation. I will first give a theoretical rationale for the exclusion restrictions that are adopted, before discussing their empirical validity.

My identification strategy utilizes the following six household status variables: being a household head; being married; working full-time; being an owner-occupier; having young children in the household; and living in a large household. These variables are associated with an individual's responsibility for the welfare of their household. It can be argued that these responsibilities reduce individuals' appetite for risky and time-consuming work options which could damage their ability to discharge their responsibilities effectively. That in turn is likely to reduce the attractiveness of starting up a venture, which is associated with high levels of risk, and which often entails heavy time commitments. Of course, it is also possible that some factors, like marriage and household size could be associated with access to greater resources which actually promote start-up activities; but the key point is that household status variables are likely to affect the probability of doing any kind of start-up relative to paid-employment. In contrast, they are not obviously associated with choices between the NI and NE modes of start-up conditional on start-up activities being chosen, since both NE and NI can be expected to entail risk and heavy time commitments.

Buttressing these arguments, previous research has emphasized the similarity of intrapreneurs and entrepreneurs in terms of personality traits and personal circumstances. It has recently been noted, 
for example, that "Intrapreneurs can be defined as entrepreneurs within existing organizations, and they closely resemble independent entrepreneurs ... Unfortunately, no clear-cut profile is available that could help to identify intrapreneurs ... many of them do share similar personality traits ... anyone who behaves with entrepreneurial spirit within an existing organization — at any level and in any function — can be an intrapreneur" (Menzel et al, 2007, p.734-35). This suggests that we are justified in excluding the six household status variables from the $I$ equation while retaining them in the $S$ equation.

The identification strategy was implemented in the following way. First, one of the six household status variables was chosen to just identify the model (it turned out not to matter which was chosen: see on). The five remaining variables were then included in (1) but excluded from (2). Second, these over-identifying restrictions were tested using a likelihood ratio test. So, for example, using Household Head as the identifying variable, the null hypothesis of acceptable exclusion restrictions was not rejected: $\chi^{2}(5)=2.34$. At the same time, the five remaining variables were individually and jointly significant determinants of $S$ (see Table 2 for parameter estimates and standard errors). Replacing Household Head with each of the other five variables as the identifying variable gave $\chi^{2}(5)$ likelihood ratio statistics ranging between 2.27 and 3.38: none of these are anywhere close to conventional levels of statistical significance either. I therefore proceed by imposing these identifying and over-identifying restrictions hereafter.

\subsection{Results based on screener data}

The first set of results appear in Table 2. These are the coefficient estimates of the bivariate probit (BVP) system. Marginal effects corresponding to these estimates appear in Table 5 (see the Appendix). Alongside the BVP results in columns 1 of Table 2 are (for comparative purposes in column 2) single-equation (Probit) estimates of $I$ [i.e., equation (2) only] without controlling for sample selection.

Regarding general human capital, the estimates of the BVP model presented in the first columns of Table 2 show that people with some college education are significantly more likely both to engage 
Table 2 Benchmark BVP and Probit estimates of NI-NE choice using Screener data

\begin{tabular}{|c|c|c|c|}
\hline & \multicolumn{2}{|c|}{$1(\mathrm{BVP})$} & 2 (Probit) \\
\hline Variables & $\mathrm{I}$ & $\mathrm{S}$ & $\mathrm{I}$ \\
\hline & \multicolumn{3}{|c|}{ Key explanatory variables } \\
\hline Constant & $1.17(0.62)^{* *}$ & $-2.01(0.11)^{* * *}$ & $-0.53(0.34)$ \\
\hline High School & $-0.32(0.18)^{*}$ & $-0.02(0.07)$ & $-0.33(0.20)$ \\
\hline Some College & $-0.39(0.16)^{* *}$ & $0.18(0.07)^{* * *}$ & $-0.39(0.20)^{* *}$ \\
\hline College Degree & $-0.28(0.18)$ & $0.08(0.07)$ & $-0.26(0.21)$ \\
\hline Postgraduate & $-0.21(0.20)$ & $0.03(0.08)$ & $-0.35(0.24)$ \\
\hline Age 18-24 & $0.29(0.19)$ & $-0.02(0.08)$ & $0.43(0.23)^{*}$ \\
\hline Age $25-34$ & $-0.04(0.17)$ & $0.15(0.07)^{* *}$ & $0.08(0.20)$ \\
\hline Age $35-44$ & $0.00(0.17)$ & $0.13(0.06)^{* *}$ & $0.06(0.18)$ \\
\hline Age $45-54$ & $0.18(0.18)$ & $0.12(0.06)^{*}$ & $0.34(0.17)^{* *}$ \\
\hline Internet & $-0.38(0.10)^{* * *}$ & $0.22(0.04)^{* * *}$ & $-0.35(0.12)^{* * *}$ \\
\hline \multirow[t]{2}{*}{ Selection, $\rho$} & \multicolumn{2}{|c|}{$-0.64(0.23)^{* * *}$} & \\
\hline & \multicolumn{3}{|c|}{ Control variables } \\
\hline Household Head & & $0.29(0.06)^{* * *}$ & $0.23(0.20)$ \\
\hline Married & & $-0.16(0.04)^{* * *}$ & $0.00(0.12)$ \\
\hline Works Full-time & & $-0.10(0.04)^{* * *}$ & $-0.15(0.11)$ \\
\hline Owner Occupier & & $-0.12(0.04)^{* * *}$ & $-0.15(0.12)$ \\
\hline Young Children & & $-0.00(0.04)$ & $0.06(0.13)$ \\
\hline Household Size & & $0.03(0.01)^{* * *}$ & $0.01(0.04)$ \\
\hline Female & $-0.18(0.14)$ & $-0.26(0.03)^{* * *}$ & $-0.37(0.11)^{* * *}$ \\
\hline African-American & $0.05(0.15)$ & $0.21(0.05)^{* * *}$ & $0.17(0.15)$ \\
\hline Latino & $0.19(0.13)$ & $-0.02(0.05)$ & $0.24(0.19)$ \\
\hline Urban & $0.07(0.09)$ & $0.03(0.04)$ & $0.25(0.11)^{* *}$ \\
\hline $\mathrm{N}$ & 9 & 09 & 909 \\
\hline$-L L$ & 402 & 7.98 & 450.28 \\
\hline
\end{tabular}

Notes: Standard errors are in parentheses. ${ }^{* * *}: p$-value less than $0.01 ;{ }^{* *}: p$-value less than $0.05 ;{ }^{*}: p$-value less than 0.10. All specifications use weighted data and include macro-regional dummies (for North-East, North-Central and South (the base region is Western): not reported). Sample size $N$ drops below 1,214 nascent intrapreneurs / entrepreneurs owing to missing observations for various explanatory variables (see Table 1). $L L$ is the maximized value of $\ln L$ in (4). Estimation method: FIML.

in start-up activities and to do so as a nascent entrepreneur (marginal effects for this variable are 0.04 and -0.14 , respectively: see Table 5 in the Appendix). The other education variables are not statistically significant at 5\%, though another measure of general human capital, namely Internet usage at home, is also strongly and significantly associated with start-up activities in general and NE organizing efforts in particular (with marginal effects of 0.04 and -0.14 , respectively). These 
findings provide some preliminary support for Hypothesis 1, which proposed that general human capital enables individuals to exploit new opportunities independently of a formal employer. The results are also consistent with Hypothesis 6, with the general human capital variables of age, college education and Internet usage all being positively associated with start-up activity of any kind.

The sample selection parameter $\rho$ is negative and highly significant. This means that people who start up new ventures rather than doing wage-and-salary work possess unobserved attributes which also predispose them to try independent starts rather than those undertaken jointly with an employer. This provides strong support for Hypothesis 5. But the sample selection issue is of further interest because were it to be ignored, giving rise to the results in column 2 of Table 2 , the researcher would be misled into making several incorrect inferences about the determinants of nascent intrapreneurship versus entrepreneurship. For instance, it would be wrongly inferred that women are much less likely to be nascent intrapreneurs than men are. In fact, the BVP results show that women are simply less likely to engage in start-up activities of either kind; once this selection is taken account of, gender differences in NI versus NE are no longer statistically significant. Other misleading inferences would also be made about the effects of age and urban location. For these reasons, it is of practical importance to eschew single-equation estimates, and to estimate the complete sample-selection model (1)-(3).

Among the controls appearing in Table 2, family structure variables help explain the decision to start a venture. This demonstrates the power of these identifying instruments. Full-time married owner-occupiers are significantly less likely than average to start a new venture of any kind. That might be because such individuals tend to be already established in successful wage-and-salary careers, and to have responsibilities to others in their household which deter them from trying selfemployment. Heads of households and members of large households are significantly more likely to engage in start-up activities, however. The marginal effects for these variables are relatively modest in size though, ranging from 0.01 to 0.06 in absolute value. As has been noted in previous 
Table 3 BVP estimates of NI-NE choice using Screener and Follow-up data

\begin{tabular}{|c|c|c|c|c|}
\hline Variables & 1 (BVP) & 2. (BVP) & 3 (BVP) & 4 (BVP) \\
\hline \multicolumn{5}{|c|}{ Key explanatory variables } \\
\hline Constant & $1.17(0.71)^{*}$ & $0.76(0.79)$ & $1.17(0.61)^{*}$ & $1.02(0.64)$ \\
\hline High School & $-0.32(0.19)^{*}$ & $-0.28(0.19)$ & $-0.42(0.19)^{* *}$ & $-0.28(0.18)$ \\
\hline Some College & $-0.41(0.18)^{* *}$ & $-0.35(0.17)^{* *}$ & $-0.51(0.17)^{* * *}$ & $-0.35(0.16)^{* *}$ \\
\hline College Degree & $-0.33(0.19)^{*}$ & $-0.24(0.19)$ & $-0.31(0.18) *$ & $-0.25(0.18)$ \\
\hline Postgraduate & $-0.20(0.21)$ & $-0.19(0.22)$ & $-0.26(0.20)$ & $-0.20(0.21)$ \\
\hline Age 18-24 & $0.15(0.21)$ & $0.35(0.21) *$ & $0.19(0.18)$ & $0.28(0.19)$ \\
\hline Age $25-34$ & $-0.13(0.18)$ & $-0.02(0.19)$ & $-0.08(0.16)$ & $-0.03(0.17)$ \\
\hline Age $35-44$ & $-0.01(0.18)$ & $-0.03(0.19)$ & $-0.05(0.16)$ & $-0.00(0.17)$ \\
\hline Age $45-54$ & $0.20(0.19)$ & $0.17(0.19)$ & $0.14(0.16)$ & $0.17(0.18)$ \\
\hline Internet & $-0.43(0.10)^{* * *}$ & $-0.42(0.11)^{* * *}$ & $-0.35(0.09)^{* * *}$ & $-0.40(0.10)^{* * *}$ \\
\hline Job Tenure & $-0.10(0.06)$ & & & \\
\hline Manager & $0.13(0.11)$ & & & \\
\hline No. of Supervisees & $-0.09(0.07)$ & & & \\
\hline B2B Sales & & $0.30(0.15)^{* *}$ & & \\
\hline Log Income & & & $0.06(0.05)$ & \\
\hline Wealth & & & $-0.06(0.08)$ & \\
\hline Unique & & & & $0.15(0.15)$ \\
\hline Competitor Information & & & & $0.15(0.10)$ \\
\hline Unique $\times$ Competitor & & & & $0.03(0.20)$ \\
\hline Selection, $\rho$ & $-0.57(0.28)^{* *}$ & $-0.53(0.30)^{*}$ & $-0.81(0.13)^{* * *}$ & $-0.63(0.23)^{* * *}$ \\
\hline $\bar{N}$ & 884 & 864 & 744 & 909 \\
\hline$-L L$ & 3895.43 & 3848.94 & 3304.86 & 4006.22 \\
\hline
\end{tabular}

Notes: The control variables appearing in the $I$ equation of Table 2 remain individually and jointly insignificant; they were included in these specifications but their coefficients and standard errors are not reported. Coefficients and standard errors for the No. of Supervisees are multiplied by 100. All specifications use weighted data and include macro regional dummies and industry dummies. See notes to Table 2.

research, African-Americans are also significantly and substantially more likely to engage in startup activities (Kim et. al. 2006) although interestingly they are no more or less likely on average to choose NI over NE start-ups.

\subsection{Results based on screener and follow-up data}

The next set of results tests the remaining hypotheses by adding sequentially further explanatory variables from the Follow-up dataset, $Z_{i}$. Table 3 presents the parameter estimates. Column 1 of Table 3 further explores Hypothesis 1 by adding three proxies for specific human capital, while 
columns 2 through 4 test Hypotheses 2 through 4 respectively. For brevity, only results from the $I$ equation are presented. Estimates of the $S$ equation are very similar to those of Table 2 and so are omitted; they are available from the author on request.

Column 1 of Table 3 shows that the three measures of specific human capital, based on length of job tenure, holding a managerial position in the current or most recent firm, and the number of supervisees, are insignificant determinants of NI start-ups relative to NE. The marginal effects of these variables are also modest, being $-0.03,0.04$ and -0.03 , respectively. In contrast, general human capital continues to have strong effects, promoting both start-up propensities and independent start-ups in particular. These findings are consistent with Hypothesis 1, and suggest that nascent entrepreneurs rely relatively more on general human capital than nascent intrapreneurs, who can exploit other resources within their employer firm (see below).

Column 2 of Table 3 adds the percentage of projected Business-to-Business sales. This variable is significantly associated with commercialization of new venture opportunities via NI rather than NE, with a fairly sizeable marginal effect of 0.10 . This supports Hypothesis 2, which argued that intrapreneurial start-up efforts are more likely than entrepreneurial ones to sell to other businesses, possibly because they can leverage greater resources and legitimacy.

The results in column 3 do not support Hypothesis 3. While log income has a positive effect on NI propensities, it is not statistically significant (and its marginal effect is only 0.02); and household wealth has the opposite (negative) sign and is also statistically insignificant (its marginal effects is -0.02). It is noteworthy that previous research reports that income and wealth have little or no explanatory power in predicting which people try to start new ventures (Delmar and Davidsson 2000; Kim et. al. 2006; Parker and Belghitar 2006). The findings in column 3 suggest that engagement in nascent intrapreneurship is not explained either by the strategic use of personal income and wealth to resolve agency problems within the firm (see the arguments leading up to Hypothesis 3).

Column 4 presents results relating to product uniqueness and competitor information acquisition. None of these effects are significant (marginal effects for the three variables are 0.05, 0.05 and 0.01, 
respectively). But these relationships strengthen in statistically more efficient specifications of the BVP sample-selection model. For example, it is possible to run stepwise estimation routines using all of the variables in the Screener and Follow-up datasets, for both the $I$ and $S$ decision choices. Details of this procedure — which is data- rather than theory-driven — together with parameter estimates, can be found in Table 6 located in the second part of the Appendix. It turns out that once insignificant covariates are dropped from the specification in Column 4, NI is significantly associated with $\mathrm{B} 2 \mathrm{~B}$ sales, unique products and acquisition of information about competitors (consistent with Hypotheses 2 and 4). The interaction between unique products and competitor information remains insignificant, however. This might suggest that incumbents gather information about competitors as a routine process, not specifically in order to reassure senior managers about the value of developing new intrapreneurial ventures (Hypothesis 4).

Results based on more parsimonious specifications of the bivariate probit sample selection model (Table 6 in the Appendix) also identify some additional determinants of the NE/NI commercialization mode. According to Table 6, the middle age groups (ages 25-44 years) are significantly more likely than average to engage in some kind of start-up, whereas the youngest people (under 25 years) as well as older (over 45 years) people in the sample are significantly more likely to be nascent intrapreneurs conditional on engaging in start-up activity at all. This finding is consistent with previous theorizing in the entrepreneurship literature (Lévesque and Minniti 2006; van Praag and van Ophem 1995). For example, drawing on van Praag and van Ophem's (1995) distinction between ability and willingness to participate in entrepreneurship, the results might suggest that people who lack the resources (the younger) or the inclination (the older) to engage in independent start-up activities can sometimes be persuaded to do so within a corporate environment.

Several other points are of additional interest. First, NI flourishes more in male-dominated workplaces than more gender-balanced workplaces. It is not clear why this is so, especially as a simple gender dummy is always insignificant in the $I$ equation of the BVP model, and as this result is robust to including controls for high-tech and new-tech industries, in which male-dominated workplaces are often found. Second, the lack of significance and hence non-appearance in Table 6 of 
dummies for high-tech or new-tech products belies the emphasis given in the corporate venturing literature to these types of venture (though see Liao and Welsch 2008, who observed that hightech and non-high-tech NEs appear to follow a common set of core start-up organizing activities). It is striking that existing corporations are willing to develop unique new products, but are no more or less willing than independent entrepreneurs to develop high-tech products based on new technologies.

\subsection{Robustness checks}

I conduct six robustness checks below. These are intended to test the sensitivity of the results with respect to: (1) the inclusion of social capital, which might be of greater importance for NE than NI; (2) the use of different measures of general human capital; (3) the inclusion of occupational dummies, since NI might be difficult or even impossible to pursue in some occupations; (4) controls for low-growth hobby businesses, which are more likely to be relevant for NE than NI; (5) the inclusion of controls for business type; and (6) investigation of the possibility that managers rather than workers decide on NI versus NE outcomes.

Regarding (1), social capital can confer legitimacy upon entrepreneurship; reveal information about opportunities, customers, suppliers and competitors; and facilitate access to resources (Florin et. al. 2003). Family, friends and the community can all be sources of social capital, which can make NE more attractive or feasible relative to NI (Freeman and Engel 2007). Based on these arguments, dummy control variables were added which record whether Parents were ever business owners or self-employed (Dunn and Holtz-Eakin 2000); whether Friends and Family offered support (Brüderl and Preisendörfer 1998); and whether the individual's community promotes Entrepreneurial Norms (Giannetti and Simonov 2004). Column 1 of Table 6 in the Appendix shows that two of these measures of social capital, namely parental self-employment and 'entrepreneurial norms', are significantly associated with NE over NI commercialization. In terms of bearing on NI versus NE outcomes, social capital seems to offer a complementary and additional explanation to human capital, since the other results remain robust to the inclusion of these variables. 
Turning to robustness check (2), the following two additional general human capital variables were available in the Follow-up: industry experience and the number of previous start-ups undertaken by individuals. It is important to check whether these variables affect the results relating to human capital. However, neither of these variables were statistically significant, having coefficients (standard errors) of $0.16(0.49)$ and $-0.02(3.46)$ respectively.

Regarding (3), data on broad occupational groups were included to deal with the possibility that opportunities vary systematically by occupation. If so, the results might merely reflect different occupational mixes between NI and NE. Controls for a variety of occupations were included, and some of them turned out to be significant, as can be seen in column 2 of Table 6 in the Appendix. In particular, blue-collar and service-sector employees are much less likely to engage in any start-up activity than their white-collar and non-service-sector counterparts are. While craft workers are no more or less likely to engage in a start-up than the average, those who do are much more likely to do so via NE than NI. This may not come as a surprise, given that artisans tend to run independent small businesses. Because of numerous missing data about occupations, the sample sizes underlying these estimates are smaller and fewer variables remain statistically significant; but the main results generally continue to hold, apart from weaker effects from human and social capital and unique products. In fact, these results should be treated with particular caution since occupations are partially determined by human capital and so could be endogenous.

Robustness check (4) recognizes that many start-ups are hobby businesses (Reynolds et. al. 2004). Corporations are invariably uninterested in such businesses, setting a higher priority on innovations which generate growth. It is therefore prudent to check whether the results are sensitive to this possibility. A dummy variable Growth Aspirations takes the value of one if this was cited by the respondent as a major motivation for the start-up, and zero otherwise. Although positive in the $I$ equation as expected, this variable turned out to be statistically insignificant, with a coefficient of 0.12 and a standard error of 0.07 . None of the other results were affected by the inclusion of this variable. 
For (5), I tested whether business type made any difference to NE and NI outcomes. Dummy variables for whether the start-up effort was a purchase or takeover of an existing business; a franchise, a multi-level marketing initiative; or a new business sponsored by an existing business were included in the BVP model. However, none of these dummies were statistically significant ( $p$-values were $0.81,0.16,0.36$ and 0.11 , respectively).

Finally, for robustness check (6), I address a possible concern about the appropriateness of using PSED II data. These data emphasize individual-level determinants of nascent intrapreneurship. But an alternative possibility is that managers within companies, rather than individuals, determine the scope for intrapreneurial exploitation. If so, use of the PSED II might be problematic. Fortunately, it is possible to perform some checks about the appropriateness of the data. First, if nascent intrapreneurship is driven by managers, one would expect significantly more NIs than NEs to obtain their business ideas within the current (or previous) workplace. Yet the proportions of $17.5 \%$ (or $23.6 \%$ ) for NIs, compared with $16.3 \%$ (or $22.5 \%$ ) for NEs, are very similar and not significantly different. Second, if managers are principally responsible for nascent intrapreneurship then one might expect more NIs than NEs to cite as reasons for starting new ventures career motivations (including taking work to the next level), and encouragement by people within the industry. Yet more NEs than NIs (2.0\% and $3.4 \%$ for NEs, compared with $1.2 \%$ and $3.2 \%$ for NIs) cited these factors as the two main influences which prompted them to try starting up a new venture. Hence it does not seem that managerial choices dominate individual-level choices, at least in the nascent stages of business venturing.

An overview of the main findings of the article is presented in Table 4, which summarizes the degree of empirical support for the six principal hypotheses examined in this study.

\section{Implications and Conclusions}

This article analyzed a recent sample of PSED II data in an attempt to isolate the factors determining whether new start-up opportunities are commercialized via nascent intrapreneurship or nascent entrepreneurship. The analysis highlighted the importance of dealing with self-selection 
Table 4 Summary of tests of the model hypotheses

\begin{tabular}{|l|l|l|l|}
\hline Hypothesis & Test statistic & p-value & Supported? \\
\hline 1. General human capital & $\chi^{2}(9)=29.49$ & $<0.01$ & Yes \\
\hline \multicolumn{1}{|c|}{ Specific human capital } & $\chi^{2}(3)=2.76$ & 0.45 & Yes \\
\hline 2. Business-to-business & $\chi^{2}(1)=3.89$ & 0.05 & Yes \\
\hline 3. Income and wealth & $\chi^{2}(2)=0.86$ & 0.65 & No \\
\hline 4. Unique and competitor information & $\chi^{2}(2)=6.26$ & 0.04 & Yes \\
\hline \multicolumn{1}{|c|}{ Interaction } & $\chi^{2}(1)=0.03$ & 0.87 & No \\
\hline 5. Self-selection & $\chi^{2}(1)=8.03$ & $<0.01$ & Yes \\
\hline 6. General h.c. and start-up activity & $\chi^{2}(9)=80.10$ & $<0.01$ & Yes \\
\hline
\end{tabular}

Notes: All test statistics are Wald statistics, with degrees of freedom in parentheses. Tests conducted on the specification in Table 6, column 1.

when investigating this issue. It turns out that unobserved attributes that predispose people against engaging in any type of start-up effort (whether intrapreneurship or entrepreneurship) rather than a corporate work environment also predispose them to favor nascent intrapreneurship over nascent entrepreneurship. It might be thought that one implication of this finding is that potential nascent intrapreneurs might neither express any interest in entrepreneurship nor seek any kind of start-up opportunity until and unless their work colleagues or managers present a suitable opportunity to them. Yet other findings emerging from the analysis cast doubt on the notion that managerial direction actually shapes nascent intrapreneurship in practice.

My findings carry some additional implications for managers. Although it might not be possible to stop employees in the 25-44 year age range from quitting to exploit their ideas in an independent start-up, it is noteworthy that the youngest and older employees are significantly more likely to engage in nascent intrapreneurship than in nascent entrepreneurship. These employees appear to be the most promising candidates for corporate venturing. And the fact that NI appears to be associated with male-dominated workplaces suggests that some work environments are more conducive to corporate venturing than others — a finding whose underlying causes are unclear and require clarification in future research. But just as some nascent intrapreneurs may respond to stimuli emanating from work environments in their employer firms, nascent entrepreneurs seem to respond positively to stimuli emanating from other people in their social networks. These include their parents and possibly also influential entrepreneurial role models in their communities. 
The results in this article also raise some questions touching on future theory development in the area of corporate versus independent venturing. An important theoretical question is whether managers can design contracts and work environments to minimize the risk that able employees quit to start their own ventures. Or do entrepreneurs' practices of copying their employer's organizational routines in independent ventures make any such efforts fruitless? A related but broader question is whether organizations can strategically groom future intrapreneurs. Another is whether managers can derive a competitive hiring advantage by positioning their organizations strategically as ones which provide supportive environments for corporate venturing. These questions all come down to managers making hard-headed decisions about their employees, work environments and corporate venturing opportunities subject to constraints imposed by the marketplace, internal rigidities and managerial capabilities.

Quite apart from being unable as yet to shed any light on these questions, this study is prone to several important limitations. One of these is the use of crude measures of specific human capital. As noted at several junctures throughout this paper, genuinely firm-specific human capital is hard to measure properly; but hopefully future research will be able to provide sharper measures of it. Another limitation of the PSED II is that it is not possible to check whether human capital is endogenous (Parker and van Praag 2006). The PSED II also lacks information about organizational culture and the ways that it can foster creativity among latent entrepreneurs within an organization's workforce. Menzel et. al. (2007) argue that organizational cultures which reduce internal barriers to change and encourage creativity tend to be best placed to foster intrapreneurship. Whether such cultures are generally desirable or even feasible probably depends on the nature of the particular organization and the phase of the relevant product life cycle.

An additional limitation is that the PSED II lacks data about non-compete agreements, which might restrict opportunities for employees to choose NE over NI. And PSED II lacks data about risk attitudes and cognitive styles of individuals (and managers). Thus if existing firms provide a 'safe' or forgiving environment within which to try a start-up, by offering high levels of support for employees who lack the confidence required to undertake independent venturing, then one might 
expect selection of individuals into NI rather than NE along these lines as well. Although previous research suggests that intrapreneurs and entrepreneurs are rather similar in these respects (Hisrich 1990; Hitt et. al. 2002), further evidence is warranted in a multivariate sample-selection setting.

As well as addressing these limitations, future research could analyze several other interesting issues which fall outside the scope of the present article. For example, we still lack precise estimates of how many new independent start-ups arise from opportunities which incumbent firms do not wish to develop, compared with ones they would have liked to develop had the employees who discovered them chosen to remain within the firm. Another set of questions relates to performance. It would be interesting to establish which of NI and NE start-up efforts reach the market the fastest - and indeed how many of them make it to market at all. The author hopes to address some of these questions as future waves of PSED II data become available.

In summary, the research findings in this article suggest that individual, organizational and product characteristics all affect decisions to exploit opportunities via intrapreneurship or entrepreneurship. The primary contribution of the paper was to shed empirical light on the precise role played by these and other determinants of entrepreneurs' mode of commercialization, while taking account of self-selection into any form of entrepreneurial activity in the first place. Given the ubiquity of over-optimism among venture founders (Cooper et. al. 1988), it remains to be seen whether the start-up efforts explored in this paper are ultimately worth the investment costs, and whether intrapreneurship enjoys any advantage over entrepreneurship in this respect. Any analysis of these questions will also need to take account of sample selection, so the methods and results presented in this paper hold out the promise of helping to answer these questions as well. 


\section{Appendix}

7.1. Marginal effects corresponding to Table 2

Table 5 (see over) 
Table 5 Marginal effects corresponding to Table 2

\begin{tabular}{|l|l|l|l|}
\hline & \multicolumn{2}{|c|}{ Individual effects } & \multicolumn{1}{c|}{ Joint effects } \\
\hline Variables & \multicolumn{1}{|c|}{ I } & \multicolumn{1}{|c|}{ S } & \multicolumn{1}{c|}{ I \& S } \\
\hline & \multicolumn{3}{|c|}{ Keyplanatory variables } \\
\hline High School & -0.11 & -0.00 & $-0.11(0.04)^{* *}$ \\
\hline Some College & -0.14 & 0.04 & $-0.10(0.05)^{* *}$ \\
\hline College Degree & -0.10 & 0.02 & $-0.08(0.05)$ \\
\hline Postgraduate & -0.07 & 0.01 & $-0.06(0.06)$ \\
\hline Age 18-24 & 0.10 & -0.00 & $0.11(0.07)$ \\
\hline Age 25-34 & -0.01 & 0.03 & $0.02(0.06)$ \\
\hline Age 35-44 & 0.00 & 0.03 & $0.03(0.06)$ \\
\hline Age 45-54 & 0.06 & 0.02 & $0.09(0.06)$ \\
\hline Internet & -0.14 & 0.04 & $-0.10(0.04)^{* *}$ \\
\hline & \multicolumn{1}{|c|}{ Control variables } \\
\hline Household Head & \multicolumn{4}{|l|}{0.06} & $0.06(0.03){ }^{* *}$ \\
\hline Married & & -0.03 & $-0.03(0.02)$ \\
\hline Works Full-time & & -0.02 & $-0.02(0.01)$ \\
\hline Owner Occupier & & -0.02 & $-0.02(0.02)$ \\
\hline Young Children & & -0.00 & $-0.00(0.01)$ \\
\hline Household Size & & 0.01 & $0.01(0.01)$ \\
\hline Female & -0.06 & -0.05 & $-0.11(0.03)^{* * *}$ \\
\hline African-American & 0.02 & 0.04 & $0.06(0.04)$ \\
\hline Latino & 0.07 & -0.00 & $0.07(0.05)$ \\
\hline Urban & 0.02 & 0.01 & $0.03(0.03)$ \\
\hline \hline
\end{tabular}

Notes: Marginal effects are the partial derivatives of $E(I \mid S=1)$ with respect to the vector of characteristics.

They are computed at sample means based on all observations. 'Individual effects' are marginal effects for each equation separately; 'Joint effects' are the total over both equations. Standard errors in parentheses.

\subsection{Stepwise procedure and results}

Following Kennedy and Gentle (1981), the stepwise approach commenced with the specification of Table 2, and entered sequentially variables with the greatest contribution to the log-likelihood $L L$. Variables with $p$-values of $10 \%$ or less were retained and those with the smallest contributions to the log-likelihood and with $p$-values of more than $10 \%$ were removed. The procedure continued until no more variables could be entered or deleted, at which point it terminated. Forward and backward strategies for the stepwise algorithm were also tried, but these led to exactly the same final results. Furthermore, checks were performed to ensure that none of the removed variables from the stepwise procedure were jointly significant with other variables. Columns 1 of Table 6 presents the terminal estimates from the stepwise procedure; columns 2 add occupational dummies (see text). 
Table 6 Stepwise parameter estimates

\begin{tabular}{|c|c|c|c|c|}
\hline & \multicolumn{2}{|c|}{1 (BVP) } & \multicolumn{2}{|c|}{2 (BVP) } \\
\hline Variables & $\mathrm{I}$ & $\mathrm{S}$ & $\mathrm{I}$ & $\mathrm{S}$ \\
\hline & \multicolumn{4}{|c|}{ Key explanatory variables } \\
\hline Constant & $1.05(0.30)^{* * *}$ & $-2.05(0.07)^{* * *}$ & $0.82(0.35)^{* *}$ & $-1.76(0.08)^{* * *}$ \\
\hline Some College & $-0.16(0.08)^{* *}$ & $0.19(0.04)^{* * *}$ & & $0.17(0.04)^{* * *}$ \\
\hline College Degree & & $0.09(0.04)^{* *}$ & & \\
\hline Age $18-24$ & $0.36(0.11)^{* * *}$ & & $0.37(0.13)^{* * *}$ & \\
\hline Age 25-34 & & $0.15(0.04)^{* * *}$ & & $0.17(0.05)^{* * *}$ \\
\hline Age 35-44 & & $0.16(0.04)^{* * *}$ & & $0.11(0.05)^{* *}$ \\
\hline Age $45-54$ & $0.20(0.09)^{* *}$ & $0.11(0.05)^{* *}$ & & $0.12(0.05)^{* *}$ \\
\hline Internet & $-0.50(0.09)^{* * *}$ & $0.22(0.04)^{* * *}$ & $-0.44(0.11)^{* * *}$ & $0.15(0.04)^{* * *}$ \\
\hline Unique Product & $0.17(0.10)^{*}$ & & & \\
\hline Competitor Information & $0.16(0.08)^{* *}$ & & $0.23(0.09)^{* *}$ & \\
\hline B2B Sales & $0.30(0.13)^{* *}$ & & $0.28(0.14)^{* *}$ & \\
\hline \multirow[t]{2}{*}{ Selection, $\rho$} & \multicolumn{2}{|c|}{$-0.65(0.12)^{* * *}$} & \multicolumn{2}{|c|}{$-0.60(0.14)^{* * *}$} \\
\hline & \multicolumn{4}{|c|}{ Control variables } \\
\hline Household Head & & $0.31(0.06)^{* * *}$ & & $0.22(0.07)^{* * *}$ \\
\hline Married & & $-0.16(0.04)^{* * *}$ & & $-0.17(0.04)^{* * *}$ \\
\hline Works Full-time & & $-0.12(0.03)^{* * *}$ & & $-0.16(0.05)^{* * *}$ \\
\hline Owner Occupier & & $-0.12(0.03)^{* * *}$ & & $-0.15(0.04)^{* * *}$ \\
\hline Female & & $-0.28(0.03)^{* * *}$ & & $-0.29(0.04)^{* * *}$ \\
\hline Household Size & & $0.04(0.01)^{* * *}$ & & $0.04(0.01)^{* * *}$ \\
\hline African-American & & $0.23(0.04)^{* * *}$ & & $0.22(0.05)^{* * *}$ \\
\hline Talked to Customers & $-0.15(0.08)^{*}$ & & $-0.19(0.09)^{* *}$ & \\
\hline Male Dominated & $0.19(0.08)^{* *}$ & & $0.27(0.10)^{* * *}$ & \\
\hline Parents & $-0.15(0.08)^{*}$ & & $-0.15(0.09)^{*}$ & \\
\hline \multirow[t]{2}{*}{ Entrepreneurial Norms } & $-0.13(0.08)^{*}$ & & & \\
\hline & \multicolumn{4}{|c|}{ Occupational dummies } \\
\hline Craft & & & $-0.36(0.13)^{* * *}$ & \\
\hline Blue Collar & & & & $-0.27(0.07)^{* * *}$ \\
\hline Service Sector & & & & $-0.22(0.06)^{* * *}$ \\
\hline $\mathrm{N}$ & & 85 & 79 & 5 \\
\hline$-L L$ & 443 & 7.26 & 355 & 7.28 \\
\hline
\end{tabular}

Notes: See the notes to Table 3. Estimation method: Stepwise FIML. Columns 1 exclude occupational dummies; columns 2 include them.

\section{References}

Aldrich, H.E. 1999. Organizations Evolving. Sage, Newbury Park CA.

Anton, J.J., D. A. Yao. 1994. Expropriations and inventions: appropriable rents in the absence of property rights. American Econ. Rev. 84 190-209.

Anton, J.J., D. A. Yao. 1995. Start-ups, spin-offs, and internal projects. J. Law Econ. EJ Org 11 362-78. 
Antoncic, B., R.D. Hisrich. 2001. Intrapreneurship: construct refinement and cross-cultural validation. $J$. Bus. Venturing 16(5) 495-527.

Audretsch, D.B. 2001. Research issues relating to structure, competition and performance of small technology-based firms. Small Bus. Econ. 16 37-51.

Audretsch, D.B., R. Thurik. 2001. Linking entrepreneurship to growth. STI Working Paper 2081/2, OECD, Paris.

Baumol, W.J., R.E. Litan, C.J. Schramm. 2007. Good Capitalism, Bad Capitalism and the Economics of Growth and Prosperity. Yale University Press, New Haven CT.

Becker, G.S. 1964. Human Capital. NBER, New York.

Bhide, A.V. 2000. The Origin and Evolution of New Businesses. Oxford University Press, Oxford.

Brüderl, J., P. Preisendörfer. 1998. Network support and the success of newly founded businesses. Small Bus. Econ. $10213-25$.

Brush, C.G., L.F. Edelman, T.S. Manolova. 2008. The effects of initial location, aspirations, and resources on likelihood of first sale in nascent firms. J. Small Bus. Man. 46(2) 159-182.

Burgelman, R.A. 1983. Corporate entrepreneurship and strategic management: insight from a process study. Man. Sci. 29(12) 1349-1365.

Burgelman, R.A. 1984. Designs for corporate entrepreneurship in established firms. California Man. Rev. 26(3) $155-166$.

Christiansen, C. 1993. The rigid disk drive industry: a history of commercial and technological turbulence. Bus. History Rev. 67 531-88.

Claycomb, C., K. Iyer, R. Germain. 2005. Predicting the level of B2B e-commerce in industrial organizations. Industrial Marketing Man. 34(3) 221-234.

Cohen, W.M., S. Klepper. 1992. The trade-off between firm size and diversity in the pursuit of technological progress. Small Bus. Econ. 4(1) 1-14.

Cooper, A.C., C.Y. Woo, W.C. Dunkelberg. 1988. Entrepreneurs' perceived chances for success. J. Bus. Venturing 3 97-108.

Davidsson, P. 2006. Nascent entrepreneurship: empirical studies and developments, Foundations $\mathcal{G}$ Trends in Entrepreneurship 2(1) 1-76. 
Davidsson, P., B. Honig. 2003. The role of social and human capital among nascent entrepreneurs. J. Bus. Venturing 18 301-333.

Delmar, F., P. Davidsson. 2000. Where do they come from? Prevalence and characteristics of nascent entrepreneurs. Entrepreneurship \& Reg. Dev. 12 1-23.

Delmar, F., S. Shane. 2004. Legitimating first: organising activities and the survival of new ventures. J. Bus. Venturing 19 385-410.

Diochon, M., T.V. Menzies, Y. Gasse. 2008. Exploring the nature and impact of gestation-specific human capital among nascent entrepreneurs. J. Developmental Entrepreneurship 13(2) 151-165.

Dunn, T., D. Holtz-Eakin. 2000. Financial capital, human capital and the transition to self-employment: evidence from intergenerational links. J. Labor Econ. 18 282-305.

Edwards, L.N., E. Field-Hendrey. 2002. Home-based work and women's labour force decisions. J. Lab. Econ. $20170-200$.

Fairlie, R.W. 2006. The personal computer and entrepreneurship. Man. Sci. 52(2) 187-203.

Fayolle, A. 2004. Entrepreneuriat: Apprendre à Entreprendre. Dunod, Paris.

Florin, J., M. Lubatkin, W. Schulze. 2003. A social capital model of high growth ventures. Academy Man. Rev. 46(3) 374-84.

Freeman, J., J.S. Engel. 2007. Models of innovation: startups and mature corporations. California Man. Rev. 50(1) 94-119.

Gartner, W.B., K.G. Shaver, N.M. Carter, P.D. Reynolds. 2004. Handbook of Entrepreneurial Dynamics. Sage, Newbury Park, CA.

Giannetti, M., A. Simonov. 2004. On the determinants of entrepreneurial activity: social norms, economic environment and individual characteristics. Swedish Econ. Pol. Rev. 11(2) 269-313.

Gompers, P., J. Lerner, D. Scharfstein. 2005. Entrepreneurial spawning: public corporations and the genesis of new ventures, 1986 to 1999. J. Finance 60 577-614.

Greene, W.H. 2003. Econometric Analysis (Fifth Edition). Prentice-Hall, New Jersey.

Helfat, C.E., M.B. Lieberman. 2002. The birth of capabilities: market entry and the importance of pre-history. Industrial and Corporate Change 11 725-760. 
Hellmann, T. 2007. When do employees become entrepreneurs? Man. Sci. 53(6) 919-33.

Henderson, R. 1993. Underinvestment and incompetence as responses to radical innovation - evidence from the photolithographic alignment equipment industry. Rand J. Econ. 24(2) 248-270.

Hisrich, R.D. 1990. Entrepreneurship/intrapreneurship. American Psychologist. 45(2) 209-222.

Hitt, M.A., R.D. Ireland, R.E. Hoskisson. 2002. Strategic Entrepreneurship: Creating a New Mindset. Blackwell Publishers, Oxford.

Hornsby, J.S., D.F. Kuratko, S.A. Zahra. 2002. Middle managers' perception of the internal environment for corporate entrepreneurship: assessing a measurement scale. J. Bus. Venturing 17(3) 253-273.

Howell, J.M., C.A. Higgins. 1990a. Champions of change: identifying, understanding, and supporting champions of technological innovations. Org. Dynamics 19(1) 40-55.

Howell, J.M., C.A. Higgins. 1990b. Champions of technological innovation. Admin. Sci. Quarterly 35(2) $317-330$.

Hvide, H. 2009. The quality of entrepreneurs. Econ. J. forthcoming.

Hvide, H.K., E.G. Kristiansen. 2007. Management of knowledge workers. Available at SSRN: ssrn.com/abstract $=900569$.

Johnson, P.S., S.C. Parker, F. Wijbenga. 2006. Nascent entrepreneurship research: achievements and opportunities. Small Bus. Econ. 27(1) 1-4.

Kennedy, W.J., J.E. Gentle. 1981. Statistical Computing. Marcel Dekker Inc., New York.

Kim, P.H., H.E. Aldrich, L.A. Keister. 2006. Access (not) denied: the impact of financial, human, and cultural capital on entrepreneurial entry in the United States. Small Bus. Econ. 27(1) 5-22.

Klepper, S. 2001. Employee start-ups in high-tech industries. Ind. $\&$ Corp. Change 10 639-674.

Klepper, S., S. Sleeper. 2005. Entry by spinoffs. Man. Sci. 51 1291-1306.

Klepper, S., P. Thompson. 2006. Intra-industry spinoffs. Mimeo.

Kuratko, D.F., R.V. Montagno, J.S. Hornsby. 1990. Developing an intrapreneurial assessment instrument for an effective corporate entrepreneurial environment. Strat. Man. J. 11 49-58.

Lévesque, M., M. Minniti. 2006. The effect of aging on entrepreneurial behavior. J. Bus. Venturing 21(2) $177-194$. 
Liao, J., H. Welsch. 2008. Patterns of venture gestation process: exploring the differences between tech and non-tech nascent entrepreneurs. J. High Tech. Man. Res. 19(2) 103-113.

Lichtenstein, B.B, N.M. Carter, K.J. Dooley, W.B. Gartner. 2007. Complexity dynamics of nascent entrepreneurship. J. Bus. Venturing 22(2) 236-261.

Lumpkin, G.T., G.G. Dess. 1996. Clarifying the entrepreneurial orientation construct and linking it to performance. Academy Man. Rev. 21(1) 135-172.

MacMillan, I.C., Z. Block, P.N.S. Narashima. 1986. Corporate venturing: alternatives, obstacles encountered, and experience effects. J. Bus. Venturing 1(2) 177-191.

Menzel, H.C., I. Aaltio, J.M. Ulijn. 2007. On the way to creativity: engineers as intrapreneurs in organizations. Technovation 27(12) 732-743.

Møen, J. 2005. Is mobility of technical personnel a source of R \& D spillovers? J. Labor Econ. 23(1) 83-114.

Nelson, R., S. Winter. 1982. An Evolutionary Theory of Economic Change. Belknap Press, Cambridge MA.

Pakes, A., S. Nitzan. 1983. Optimum contracts for research personnel, research employment, and the establishment of 'rival' enterprises. J. Labor Econ. 1(4) 345-365.

Parker, S.C., Y. Belghitar. 2006. What happens to nascent entrepreneurs: an econometric analysis of the PSED. Small Bus. Econ. 27(1) 81-101.

Parker, S.C., C.M. van Praag. 2006. Schooling, capital constraints and entrepreneurial performance: the endogenous triangle. J. Bus. Econ and Statistics 24 416-431.

Pinchot, G. 1985. Intrapreneuring: Why You Don't Have to Leave the Corporation to Become an Entrepreneur. Harper \& Row, New York.

Praag, C.M. van, H. van Ophem. 1995. Determinants of willingness and opportunity to start as an entrepreneur. Kyklos 48 513-40.

Reynolds, P.D. 2009. Screening item effects in estimating the prevalence of nascent entrepreneurs. Small Bus. Econ. In press.

Reynolds, P.D., N.M. Carter, W.B. Gartner, P.G. Greene. 2004. The prevalence of nascent entrepreneurs in the United States: evidence from the PSED. Small Bus. Econ. 23 263-84.

Subramanian, N. 2005. The economics of intrapreneurial innovation. J. Econ. Behav. E Org. 58 487-510. 
Teece, D. 1986. Profiting from technological innovation: implications for integration, collaboration, licensing, and public policy. Res. Pol. 15 285-305.

Wagner, J., R. Sternberg. 2004. Start-up activities, individual characteristics, and the regional milieu, Annals Reg. Sci. 38 219-40.

Zahra, S.A., D.M. Gravis. 2000. Entrepreneurship and firm performance: the moderating effect of international environmental hostility. J. Bus. Venturing 15(5/6) 469-492.

Zucker, L.G., M.R. Darby, M.B.Brewer. 1998. Intellectual human capital and the birth of US biotechnology enterprises, American Econ. Rev. 88(1) 290-306. 